\title{
Decreased signal transducers and activators of transcription (STAT) protein expression in lymphatic organs during EAE development in mice
}

\author{
Wen Xuan Wu' ${ }^{1}$, Ling Zuo ${ }^{2}$, Kimberly E. Dine ${ }^{1}$ and Kenneth S. Shindler ${ }^{*}$ \\ *Correspondence: kenneth.shindler@uphs.upenn.edu \\ ${ }^{1}$ Scheie Eye Institute and F.M. Kirby Center for Molecular Ophthalmology, University of Pennsylvania, Philadelphia, PA, USA. \\ ${ }^{2}$ Department of Ophthalmology, Second Hospital of Jilin University, Jilin, China.
}

\begin{abstract}
Experimental autoimmune encephalomyelitis (EAE) is mediated by myelin-specific CD4 ${ }^{+} \mathrm{T}$ cells secreting Th1 and/or Th17 cytokines. Signal transducer and activator of transcription (STAT) family proteins have essential roles in transmitting Th1 and/or Th17 cytokinemediated signals. However, most studies demonstrating the importance of the STAT signaling system in EAE have focused on distinct members of this family, often looking at their role specifically in the central nervous system, or in vitro. There is limited information available regarding the temporal and spatial expression patterns of each STAT protein and interplay between STAT proteins over the course of EAE development in critical lymphatic organs in vivo. In the present study, we demonstrate dramatic and progressive decrease of all six STAT family members (STAT1, STAT2, STAT3, STAT4, STAT5, STAT6) in the spleen and lymph nodes through the course of EAE development in SJL/J mice, in contrast with almost steady expression of thymic STAT proteins. Decreased splenic and lymphatic STAT expression was accompanied by significant enlargement of the spleen and lymph nodes, and histological proliferation of T cell areas with remodeling of the splenic microstructure in EAE mice. All STAT family members except STAT2 were mainly confined in T cell areas in spleen, whereas they were distributed in a protein specific manner in thymus. We present here a comprehensive analysis of all six members of the STAT family in spleen, lymph nodes and thymus through the development phase of EAE. Results suggest that EAE induced inflammatory $\mathrm{T}$ cells may develop distinct biological features different from normal splenic T cells due to altered STAT signaling. Keywords: Signal transducer and activator of transcription, signalling, experimental autoimmune encephalomyelitis , multiple sclerosis, mice
\end{abstract}

\section{Introduction}

Experimental autoimmune encephalomyelitis (EAE) in mice is a commonly used animal model of multiple sclerosis (MS) that has provided valuable insight into the pathobiology of the human disease $[1,2]$. EAE is induced in mice by active priming with myelin proteins or specific myelin peptide epitopes in adjuvant. Demyelination and paralytic episodes are associated with infiltration of myelin-specific inflammatory Th1 $\mathrm{CD}^{+} \mathrm{T}$ cells into the central nervous system (CNS) [3]. Although initially described as an IL-12 driven Th1 cell mediated disease, it was recently shown that EAE can also be an IL-23 driven Th17 cell mediated disease [4]. Moreover, EAE can be induced by adoptive transfer of myelin-specific $\mathrm{CD}^{+} \mathrm{T}$ cells [5]. All the above data demonstrate the significance of $T$ cells in $E A E$ induction [6]. However, the mechanisms which underlie T cell proliferation and differentiation associated with EAE induction and development are not fully understood, and details of the signaling pathways that induce Th1 or Th17 cells in EAE are complex and not completely known.

It has been shown that the cytokine milieu is important for $\mathrm{CD}^{+} \mathrm{T}$ cell proliferation and differentiation [4]. Signal transducer and activator of transcription (STAT) family proteins have essential roles in transmitting many cytokine-mediated signals and thereby have similarly crucial roles in Thelper cell proliferation and differentiation [7]. The binding of cytokines to their cognate receptors differentially activates 6 STAT proteins (STAT1-6) [8], which in turn regulate the expression of genes involved in T cell homeostasis, growth, differentiation, apoptosis and immune response [7]. Previous studies demonstrated that blocking of IL-12 in Th1 cells [9] or IL-17A in Th17 cells [10,11], two cytokines that signal through the Janus Kinases (JAK)-STAT pathway, suppressed EAE development $[12,13]$. Therefore, the STAT signaling pathway has been targeted as a site for potential intervention for EAE and MS treatment [9-11,13-15].

While a role of STAT signaling in EAE has been suggested, studies are limited. However, studies in other models have demonstrated the general importance of this pathway in maintenance of the cellular integrity and healthy growth of T cells. For example, dysregulation of the JAK-STAT pathway plays a role in many primary human T cell lymphomas [16], and STAT knockout mice exhibit severely impaired lymphoid development and differentiation [17]. Specifically, STAT1 [18] and STAT4 $[19,20]$ function predominantly in promoting Th1 cell differentiation [21], whereas STAT3 is a key signaling molecule essential for Th17 lineage commitment [22]. STAT6 triggers Th2 cell devotion [23], and IL-2-activated STAT5 facilitates Treg cell differentiation [24].

Thus, the importance of the STAT signaling system in T cell development, differentiation, and survival is well established. However, studies of the importance of STAT signaling in EAE

(C) 2013 Shindler et al. licensee Herbert Publications Ltd. This is an Open Access article distributed under the terms of Creative Commons Attribution License (http://creativecommons.org/licenses/by/3.0). This permits unrestricted use, distribution, and reproduction in any medium, provided the original work is properly cited. 
Xuan Wu et al. Immunology Innovation 2013,

http://www.hoajonline.com/journals/pdf/2053-213X-1-3.pdf

doi: 10.7243/2053-213X-1-3

development have largely focused on just one or two specific STATs, often examining the role in the CNS $[\mathbf{2 5}, \mathbf{2 6}]$ or in vitro [10]. In contrast, less information is available from lymphatic organs in vivo in EAE. This is important to examine because EAE is a systemic autoimmune disease, with myelin-reactive $T$ cells first generated and expanded in the peripheral lymphatic system. Prior limited studies examining effects of STAT deletion on CNS inflammation in EAE are likely downstream effects, influenced by $T$ cell differentiation and proliferation in the periphery prior to cells gaining entry into the CNS. The temporal and spatial expression patterns of all members of the STAT family over the course of EAE development and the interplay between STAT proteins in mediating T cell proliferation and differentiation in critical lymphatic organs in vivo are not known. In the current studies, we defined the time course of changes in STAT expression in relation to the development of EAE in primary (thymus) and secondary (spleen and lymph nodes) lymphatic organs. We characterize the cell types and histological microstructure in those lymphatic organs in order to identify altered distribution of STAT proteins.

\section{Materials and methods}

Mice

Eight-week-old female SJL/J mice $(n=34)$ were purchased from the Jackson Laboratory (Bar Harbor, ME) for induction of EAE. Treatment of animals was reviewed and approved by the Institutional Animal Care and Use Committee at the University of Pennsylvania.

\section{Induction of EAE}

EAE was induced as previously described [27]. Briefly, eightweek-old female SJL/J mice, each weighing $20 \mathrm{~g}(20 \pm 1 \mathrm{~g})$ were anesthetized with ketamine/xylazine and were injected subcutaneously at two sites on the back with $0.1 \mathrm{~mL}$ solution containing $0.5 \mathrm{mg} / \mathrm{mL}$ proteolipid protein peptide 139-151 (PLP; GenScript, Piscataway, NJ) emulsified in complete Freund's adjuvant (CFA; Difco, Detroit, MI) containing 0.5 $\mathrm{mg} / \mathrm{mL}$ mycobacterium tuberculosis (Difco). Control mice were injected with equal volumes of PBS and CFA. All mice were injected with $200 \mathrm{ng}$ pertussis toxin (List Biological, Campbell, CA) in $0.1 \mathrm{~mL}$ PBS intraperitoneally on day 0 (day of immunization) and again on day 2 .

Thymus, lymph nodes and spleen were harvested from mice on day $5(n=12$, six animals for each group, Control and $E A E$, respectively) and day $10(n=12$, six animals/group) post-immunization. On day 12 ( $\mathrm{n}=10$, five animals/group), only thymus and spleen were harvested. Harvested thymus and spleen were weighed first before being frozen in liquid nitrogen and then stored at $-80^{\circ} \mathrm{C}$ until being used for protein extraction for Western blot analysis. A portion of thymus and spleen from two mice of each group was embedded in OCT compound (Sakura Finetek, Torrance, CA), slowly frozen on dry ice, and stored at $-80^{\circ} \mathrm{C}$ for sectioning for immunohistochemical analysis.

\section{Antibodies}

All rabbit anti-mouse STAT antibodies (STAT1, STAT2, STAT3, STAT4, STAT5 and STAT6) were purchased from Santa Cruz (Dallas, TX) and used at a dilution of 1:200 for both Western blot and immunohistochemical analysis, except for STAT1, for which a dilution of 1:10,000 was used. The STAT5 antibody detects both STAT5 A and B isoforms. The mouse anti-human $\beta$-actin antibody was purchased from Sigma (Sigma-Aldrich, St. Louis, MO).

\section{Protein extraction}

Protein was extracted from cytosolic and nuclear cellular fractions. Thymus, lymph nodes and spleen were ground into small pieces, homogenized in TED buffer $(50 \mathrm{mM}$ Tris [pH 7.4], $10 \mathrm{mM}$ EDTA, and $1 \mathrm{mM}$ diethyldithiocarbamic acid (DEDTC)) containing $2 \mathrm{mM}$ octyl glucoside, and centrifuged at $16,000 \times \mathrm{g}$ for $30 \mathrm{~min}$ at $4^{\circ} \mathrm{C}$. The supernatant (cytosol) was retained and stored at $-80^{\circ} \mathrm{C}$ until used for electrophoretic analyses. The crude pellets containing cell nuclei from the spleens, lymph nodes and thymus were sonicated (8-sec cycle, three cycles; Branson Sonifier, Danbury, CT) in 500 $\mu 1$ TED sonication buffer (20 mM Tris [pH 7.4], 50 mM EDTA, and $0.1 \mathrm{mM}$ DEDTC containing $45 \mathrm{mM}$ octyl glucoside). The sonicates were centrifuged at $16,000 \times \mathrm{g}$ for $25 \mathrm{~min}$ at $4^{\circ} \mathrm{C}$. The recovered supernatants were stored at $-80^{\circ} \mathrm{C}$ until electrophoretic analyses were performed. In lymph nodes, STAT expression was only analyzed in the nuclear fraction since STAT expression in spleen was almost identical in both cytosolic and nuclear compartments.

\section{Western blotting}

The protein concentration was determined in both cytosolic and nuclear fractions using the BCA protein assay according to the manufacturer's instructions (ThermoFisher Scientific, Rockford, IL). Proteins ( $30 \mu \mathrm{g} / \mathrm{lane}$ ) were then separated by $7.5 \%$ SDS-PAGE and electrophoretically transferred to a nitrocellulose membrane with use of a Bio-Rad transfer blot cell. The membranes for immunoblotting were blocked with 2\% BSA in 10 mM Tris-Cl buffer containing 0.1\% Tween 20. After blocking, blots were incubated with rabbit anti-mouse STAT1, STAT2, STAT3, STAT4, STAT5 or STAT6 antibodies at $4^{\circ} \mathrm{C}$ overnight, then washed and incubated with peroxidaseconjugated goat anti-rabbit IgG (Amersham Life Sciences, Arlington Heights, IL) at room temperature for $1 \mathrm{~h}$. After each antibody incubation, blots were washed four times (10 min each) in wash buffer. Protein bands were visualized by means of an enhanced chemiluminescence Western blotting detection kit (Amersham). To determine the molecular size of the proteins, standard molecular weight marker protein (Bio-Rad) was run in an adjacent lane. For normalization of signals, blotted membranes were stained for $\beta$-actin (Sigma). The intensity of each band was determined using Image J software (NIH.gov). Briefly, the first band is framed with the rectangle selection tool in Image J, then the "Analyze-Gels-Select Next Lane" 

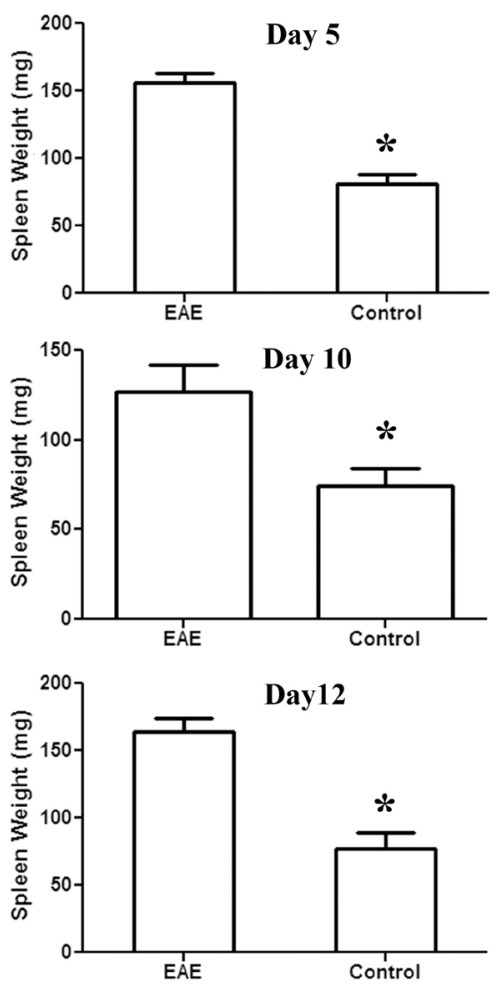

Figure 1. Comparison of the wet weight of spleens isolated from EAE $(n=5-6)$ and control $(n=5-6)$ mice. There was a significant increase of the weight of the spleen in EAE mice on day 5, day 10 and day 12 postimmunization $\left({ }^{*} \mathrm{P}<0.01\right)$, with the weight of spleens from EAE mice found to be double the weight of spleens from control mice.

command is used to select an equal area in adjacent lanes. Average pixel intensity is plotted across the selection box in each lane, with the protein band seen as a peak above the background pixel intensity. The area under the peak is calculated. For each protein, the band intensity (area under the peak) is normalized to the band intensity of the betaactin band in each lane calculated by the same method.

\section{Immunocytochemistry}

Frozen thymus and spleen were sectioned at $5 \mu \mathrm{m}$ on a cryostat (Microm HM 550, ThermoFisher Scientific, Kalamazoo, $\mathrm{MI})$. There were not enough lymph nodes to proceed with immunohistochemistry in the same animals after the tissue was used for protein extraction for Western blot analysis. Sections were stained for detection of STAT proteins using the avidinbiotin complex method (Elite kits, containing avidin [solution A] and biotin [solution B]; Vector Laboratories, Burlingame, CA). Sections were first fixed in 3.7\% formaldehyde (Fisher Scientific) at room temperature followed by incubation in cold methanol for $4 \mathrm{~min}$ and acetone for $1 \mathrm{~min}$ at $-20^{\circ} \mathrm{C}$. The sections were then rinsed with $0.05 \mathrm{M}$ Tris- $\mathrm{Cl}$ (TBS), $\mathrm{pH} 7.4$ two times ( $5 \mathrm{~min}$ each). All sections were incubated with the primary antibodies (STAT1, STAT2, STAT3, STAT4, STAT5, or STAT6) overnight at $4^{\circ} \mathrm{C}$. Sections were then rinsed 2 times (5 min each) in TBS before incubation with biotinylated goat anti-rabbit IgG in TBS for $1 \mathrm{~h}$ at room temperature, then rinsed 2 times ( 5 min each) in TBS. Finally, the sections were transferred to $A B$ solution $(22.5 \mu \mathrm{l}$ solution $A$ and $22.5 \mu \mathrm{l}$ solution $B$ in $10 \mathrm{ml} \mathrm{TBS}$ ) for $30 \mathrm{~min}$. The $A B$ solution was made at least 30 min prior to use. Immunostaining for all STATs was visualized with 3,3-diaminobenzidine tetrahydrochloride ( $D A B$; Sigma), followed by hematoxylin counterstaining. Specificity of immunostaining was verified by including the following controls: 1) no addition of primary antibody, 2) replacement of primary antibodies with normal rabbit or normal mouse serum, 3) Western blot analysis.

\section{Statistical analysis}

Each STAT protein expression level was calculated as the ratio of the Western blot band intensity of STAT: $\beta$-actin. Comparison of the mean protein expression level between groups (Control: $n=5-6$ vs EAE: $n=5-6$ per group) was made by unpaired Student's $t$-test. Statistical significance was assumed at the $5 \%$ level. Data were presented throughout as mean \pm SEM.

\section{Results}

\section{Enlarged spleen in EAE mice}

EAE was induced in 8 week old female SJL/J mice by immunization with PLP. At the time of sacrifice, the spleen and thymus were removed and weighed. There was a significant increase of the average wet weight of the spleens from EAE mice on days 5,10 and 12 post-immunization, which were approximately double the average spleen weight of control mice (Figure 1). There was no significant change in the average thymus weight between EAE and control mice (data not shown). The visualized size of lymph nodes dissected at the time of sacrifice was also noted to be larger in EAE mice than in control mice (data not shown).

\section{Stat expression is significantly decreased in the spleen during EAE development}

STAT proteins move between cytoplasm and nuclei [28], therefore, each STAT family member was quantified in both cytoplasmic and nuclear extracts isolated from thymus and spleen. We first examined expression of all six STAT proteins in the primary (thymus) and the secondary (spleen) lymphatic organs of EAE mice 12 days post-immunization, the peak time of onset of EAE [27]. Protein was extracted from 10 mice (five controls and five EAE). Western blot analysis demonstrated that expression of all STAT family members, except STAT2, decreased significantly ( ${ }^{* *} \mathrm{P}<0.01,{ }^{*} \mathrm{P}<0.05$, Figures $2 \mathrm{~A}$ and $2 \mathrm{~B}$ ) in EAE mice in both cytosolic and nuclear fractions of protein extracts isolated from spleen. No significant change in STAT2 level was found (Figures 2A and 2B). In contrast, in the thymus only STAT5 levels decreased significantly in EAE mice (Figure 3). 


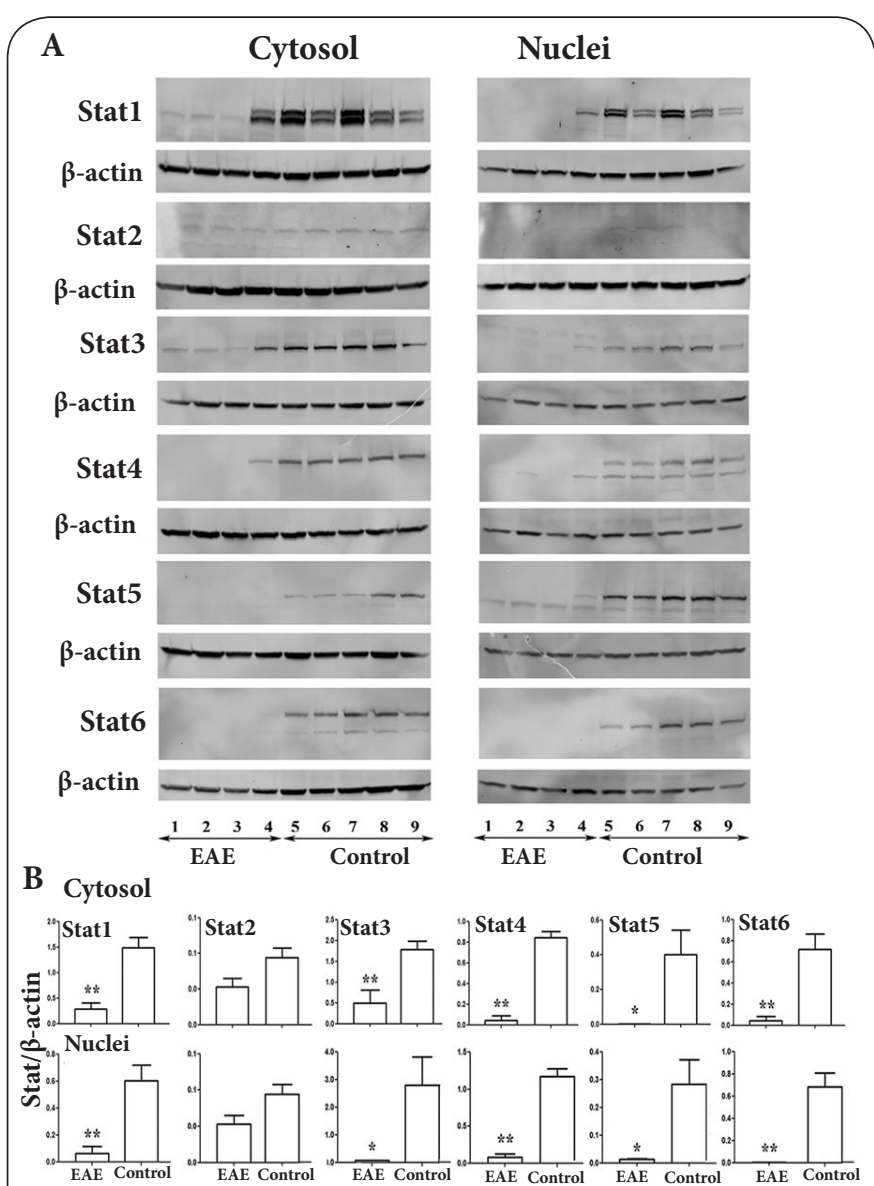

Figure 2. Protein was extracted from spleens isolated from EAE mice 12 days post-immunization. (A) Western blot of protein extracts demonstrates expression of STAT family members in spleens of EAE (lanes 1-4, $n=4$ ) and control mice (lanes 5-9, $\mathrm{n}=5$ ). Expression was analyzed in both cytosolic (left column) and nuclear (right column) fractions of protein extracts. $\beta$-actin expression was also quantified in each lane. (B) Densitometry analysis of Western blots was used to quantify STAT protein expression, presented as a ratio of the density of the STAT protein band to the $\beta$-actin band. There was a significant decrease $\left({ }^{*} \mathrm{P}<0.05 ;{ }^{*} \mathrm{P}<0.01\right)$ of STAT1, STAT3, STAT4, STAT5 and STAT6 protein levels in both cytosolic (top row) and nuclear (bottom row) fractions of protein extracts from the spleens of EAE mice as compared with spleens from control mice. In contrast, STAT2 expression did not change in either cytosolic or nuclear extracts of spleen after EAE induction. Values are presented as mean \pm SEM.

A trend of decline in the level of expression of STAT6 in thymus from either cytosolic or nuclear extracts of EAE mice did not reach statistical significance (Figure 3 ).

Time course of changes in splenic, lymphamatic and thymic stat expression during development of EAE Because significant changes in expression levels of almost all members of the STAT family were noted in splenic protein extracts at peak onset of EAE, STAT expression was also measured at earlier time points to assess temporal changes in protein levels. Spleen, lymph nodes and thymus were isolated from
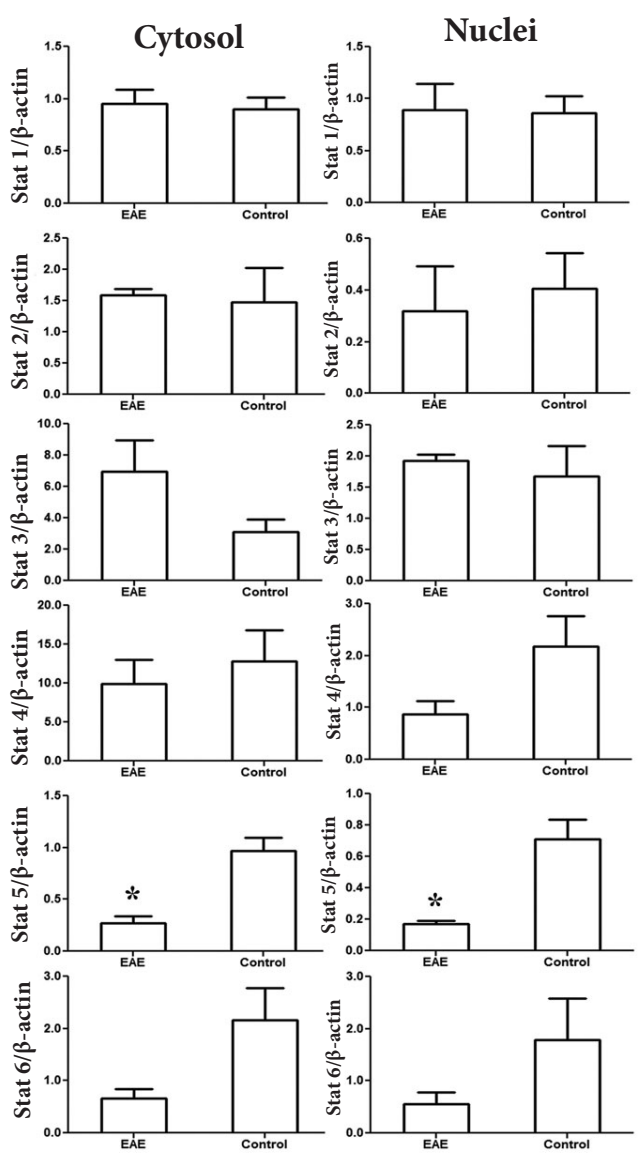

Figure 3. Protein was extracted from thymuses isolated from EAE mice 12 days post-immunization. The density of bands on Western blots of thymic protein extracts are shown as a ratio of the STAT1, STAT2, STAT3, STAT4, STAT5 or STAT6 band density to the $\beta$-actin band density. Thymic protein extracts from EAE $(n=4)$ and control $(n=5)$ mice were separated into cytosolic (left column) and nuclear (right column) fractions. There was a significant decrease $\left({ }^{*} \mathrm{P}<0.05\right)$ of STAT5 expression in both cytosolic and nuclear fractions from EAE mice as compared with extracts from control mice. There was a trend toward decreased expression of STAT6 protein in both cytosolic and nuclear fractions from EAE mice, however this did not reach significance $(\mathrm{P}>0.05)$. STAT1, STAT2, STAT3 and STAT4 levels were equivalent between EAE and control mice. Values are presented as mean \pm SEM.
SJL/J mice on day 5 (prior to onset of any clinical EAE symptoms) and day 10 (earliest onset of EAE symptoms in some mice) post-immunization. 12 mice (six controls and six EAE) were sacrificed at each time point. On day 5 , there was a significant decrease in expression of STAT4 $\left({ }^{* *} \mathrm{P}<0.01\right.$, Figures $4 \mathrm{~A}$ and $4 \mathrm{~B}$ ) and STAT5 $\left({ }^{* *} \mathrm{P}<0.01\right.$, Figures $4 \mathrm{~A}$ and $\left.4 \mathrm{~B}\right)$ proteins in both cytosolic and nuclear fractions isolated from the spleen of EAE mice as compared with control mice, while STAT3 and STAT6 only significantly decreased in the splenic nuclear extract from EAE mice $\left({ }^{*} \mathrm{P}<0.01\right)$ and remained the same as levels found in control mice in the cytosolic extracts $(P>0.05$, 


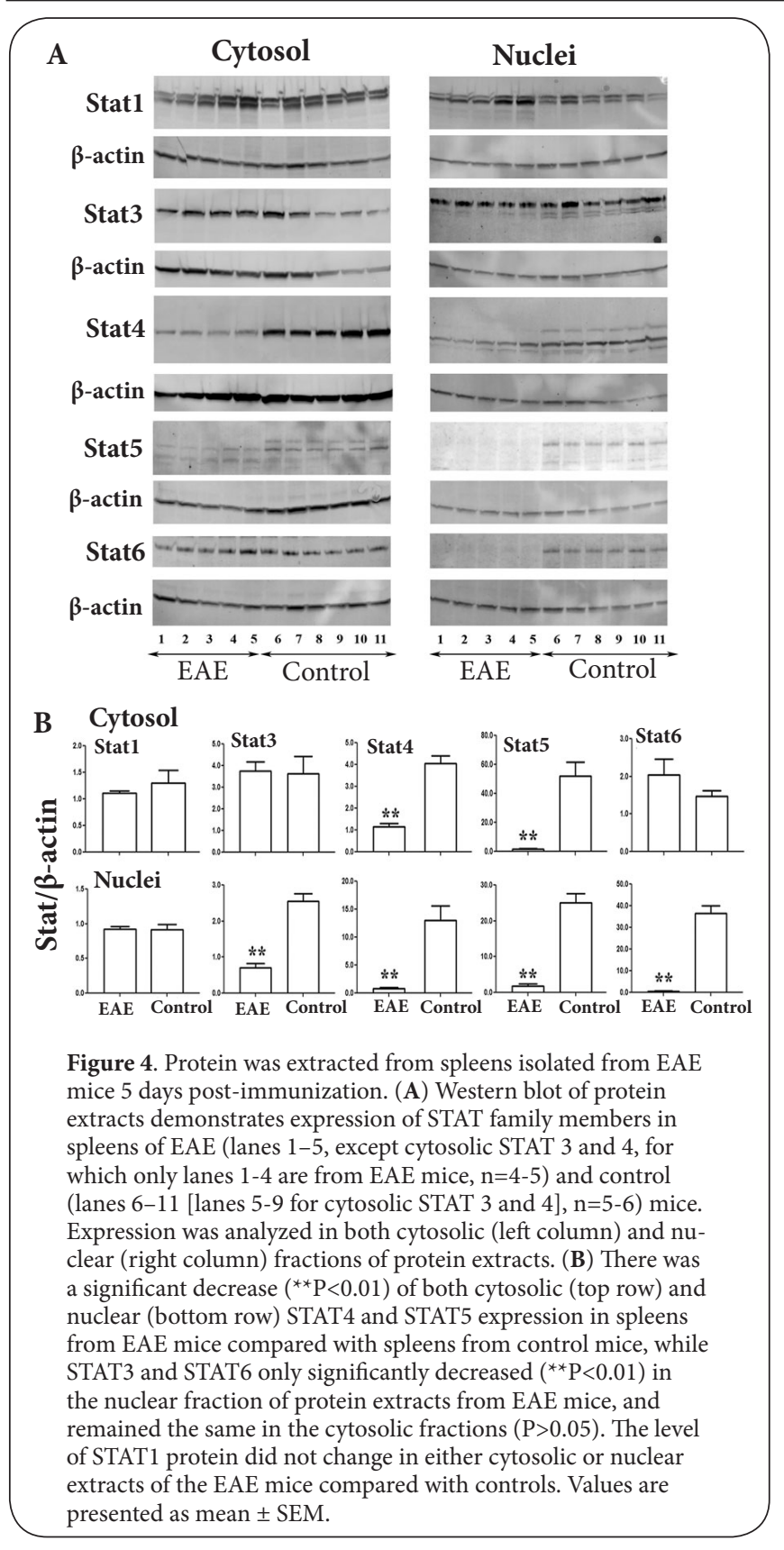

Figures 4A and 4B). The level of STAT1 protein in the spleen did not change in either cytosolic or nuclear extracts of the EAE mice compared with control mice on day 5 (Figures 4A and 4B). There was no change in expression levels of any STAT family members in the thymus in either cytosolic or nuclear extracts in EAE mice as compared to control mice on day 5 (Figure 5), and similarly the level of all six STAT proteins in extracts from lymph nodes of EAE mice was equal to lymph node expression levels in control mice, in both nuclear (Figure 6) and cytosolic fractions (data not shown), on day 5.

There was a more prominent and consistent decrease (Figures 7A and 7B) in expression of all STAT proteins in the spleen of EAE
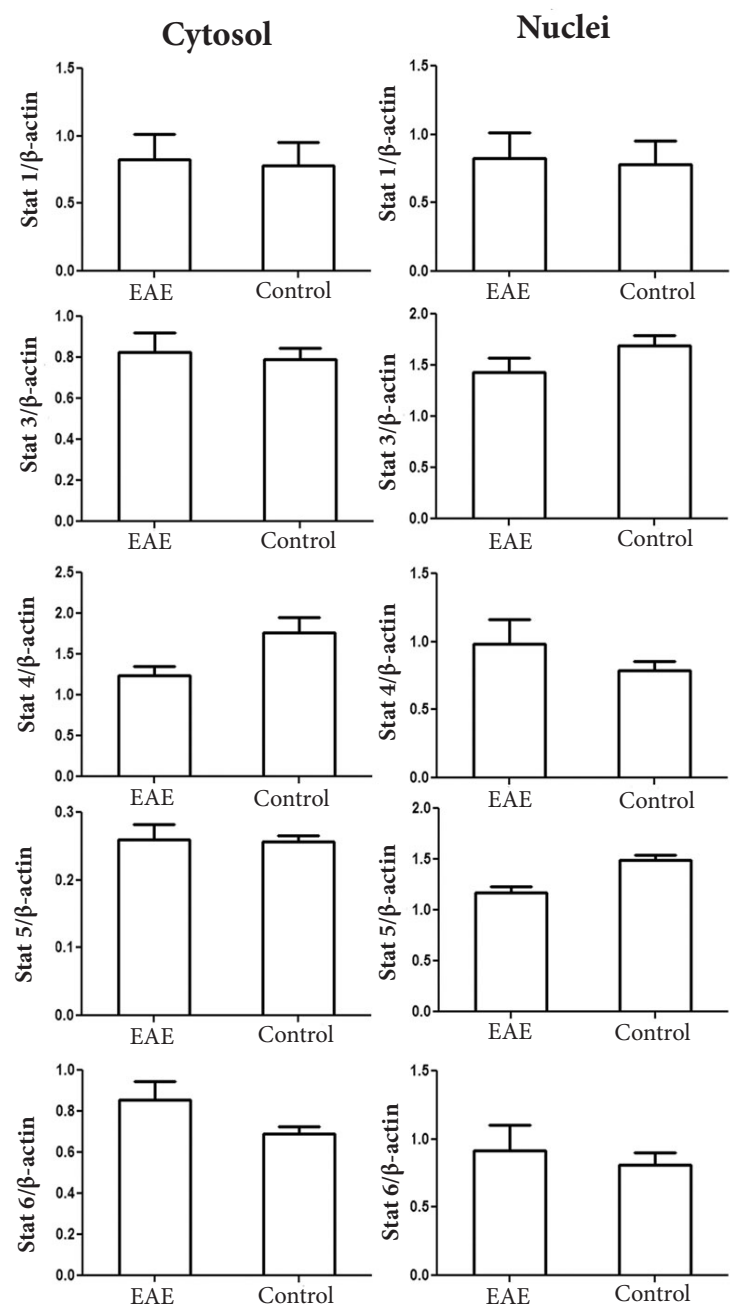

Figure 5. Protein was extracted from thymuses isolated from EAE mice 5 days post-immunization. The density of bands on Western blots of thymic protein extracts are shown as a ratio of the STAT1, STAT3, STAT4, STAT5 or STAT6 band density to the $\beta$-actin band density. Thymic protein extracts from EAE $(n=5)$ and control $(n=6)$ mice were separated into cytosolic (left column) and nuclear (right column) fractions. Expression levels of all five STAT proteins in either cytosolic or nuclear extracts from EAE mice were equivalent to levels in control mice $(\mathrm{P}>0.05)$. Values are presented as mean \pm SEM.

mice on day 10 post-immunization. Analysis of both cytosolic and nuclear fractions of protein extracts from spleen showed significantly lower levels of STAT1, STAT4, STAT5 and STAT6 in EAE mice ( ${ }^{* *} \mathrm{P}<0.01$, Figures $7 \mathrm{~A}$ and $7 \mathrm{~B}$ ) as compared with control mice. STAT3 was only reduced in the nuclear $\left({ }^{* *} \mathrm{P}<0.01\right.$, Figures $7 \mathrm{~A}$ and $7 \mathrm{~B}$ ), but not cytosolic ( $\mathrm{P}>0.05$, Figures $7 \mathrm{~A}$ and $7 \mathrm{~B}$ ) fractions of protein extracts from EAE mouse spleens. STAT2 protein was not detectable in splenic extracts from any mice on day 5 or day 10 (data not shown) post-immunization. Similar to splenic STAT proteins, protein levels of all STAT family members, except STAT1, were lower in lymph node extracts from EAE animals as compared with extracts from 


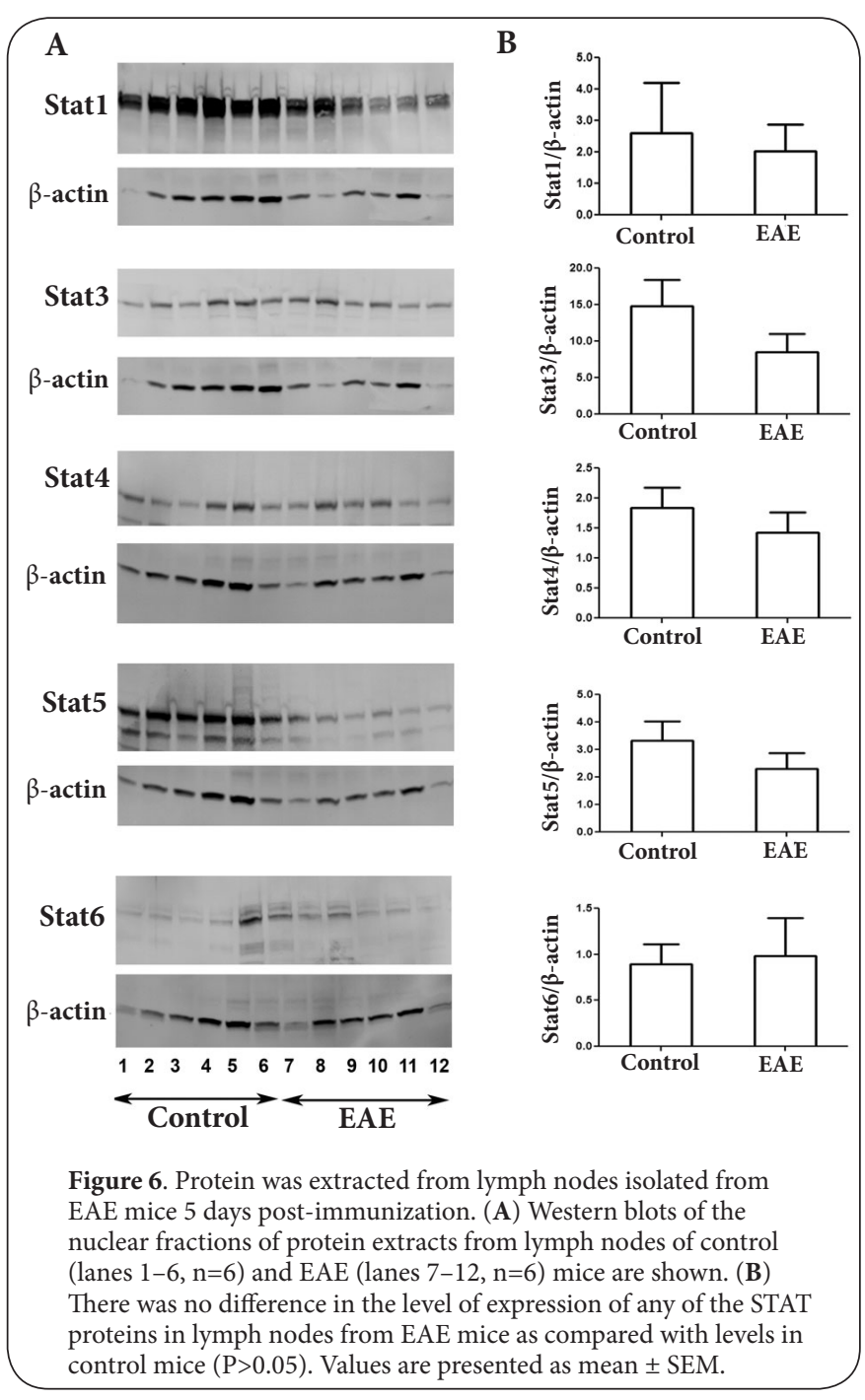

control mice, although the decrease in STAT5 did not reach statistical significance (Figure 8).

STAT1, STAT3, STAT4, STAT5 and STAT6 protein levels in both cytosolic and nuclear fractions of extracts from thymus of EAE mice isolated 10 days post-immunization were no different than levels found in control mice (Figure 9). STAT2 was not detectable in protein extracts from the thymus of any mice on day 5 or day 10 (data not shown).

\section{Immunolocalization of stat proteins in the spleen and thymus}

Because profound changes in protein expression levels of most STAT family members were observed in EAE, immunohisto-chemical staining of tissue sections was used to determine the pattern of STAT expression and to localize changes within spleen and thymus. Spleen and thymus were dissected from control and EAE mice following sacrifice on day 12 post-immu-nization. Tissues were frozen, cut into $5 \mu \mathrm{m}$ sections, and stained with antibodies to specific STAT

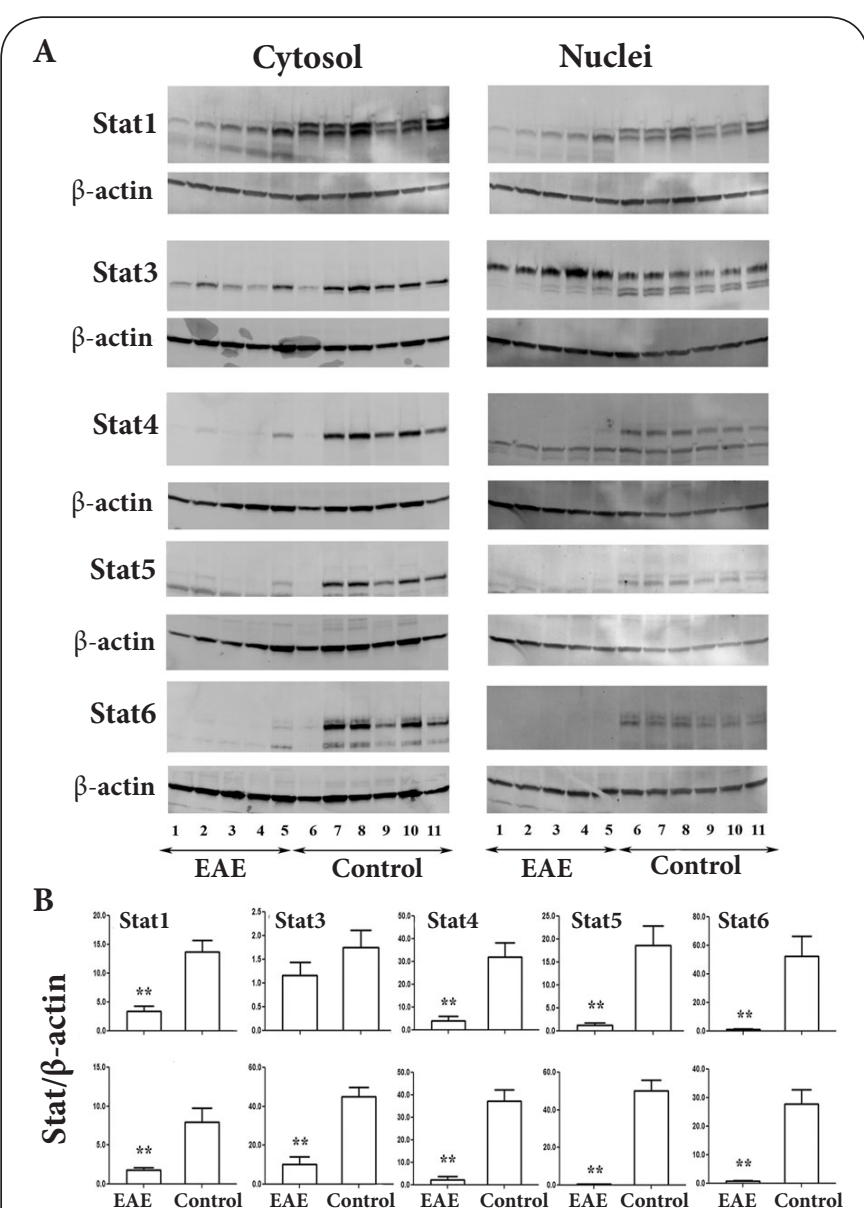

Figure 7. Protein was extracted from spleens isolated from EAE mice 10 days post-immunization. (A) Western blot of protein extracts demonstrates expression of STAT family members in spleens of EAE (lanes 1-5, n=5) and control (lanes 6-11, n=6) mice. Expression was analyzed in both cytosolic (left column) and nuclear (right column) fractions of protein extracts. (B) There was a significant decrease $\left({ }^{\star *} \mathrm{P}<0.01\right)$ of both cytosolic (top row) and nuclear (bottom row) expression of STAT1, STAT4, STAT5 and STAT6 proteins in spleens from EAE mice compared with spleens from control mice, while STAT3 only significantly decreased $\left({ }^{*} \mathrm{P}<0.01\right)$ in the nuclear fraction of protein extracts from EAE mice. Values are presented as mean \pm SEM.

family members for immunohistochemical visualization of STAT protein expression. In sections of spleen from control mice (Figure 10A-10F, the top row), STAT1 (A), STAT2 (B), STAT3 (C), STAT4 (D), STAT5 (E) and STAT6 (F) proteins were mainly localized in the T cell area of the white pulp, with predominantly nuclear staining (Figure 10A-10F). In sections of thymus from control mice (Figure 10G-10L, the bottom row), immunostaining for STAT proteins (G: STAT1; H: STAT2; I: STAT3; J: STAT4; K: STAT5; L: STAT6) was also localized within nuclei, except STAT2 $(\mathrm{H})$, which was present in both cytoplasm and nuclei.

There was enormous histological reconstruction of the immunostaining pattern in spleens isolated from EAE mice (Figure 11), as compared to the pattern in control mouse 
Xuan Wu et al. Immunology Innovation 2013,

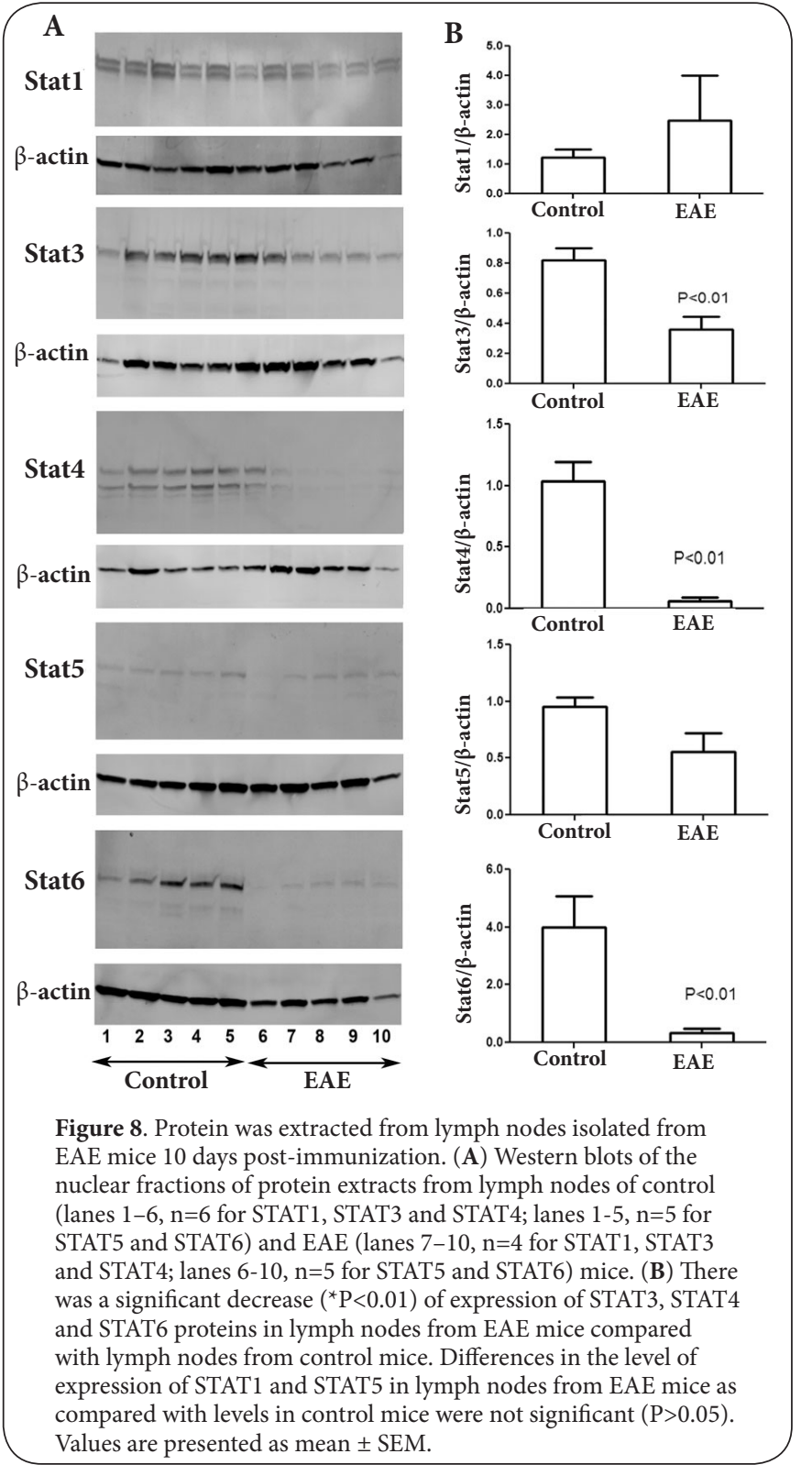

spleens. Multiple circular secondary lymphatic follicles were observed, with excessive proliferation of T cell areas. Immunostaining for all STAT proteins in spleens from EAE mice was mainly confined within these follicles, except STAT2, which was localized in all other areas of the spleen, but excluded from the $T$ cell areas of the follicles. In sections of spleens from control mice, immunostaining for all STAT proteins was observed in both red as well as white pulp (Figure 11, the top row), whereas in spleens from EAE mice (Figure 11, the bottom row) all STAT proteins except STAT2 were primarily localized in the T cell areas of the newly formed follicles. The wider distribution of STAT protein expression shows that the number of positively stained cells was larger in spleens from control mice than in spleens from EAE mice (Figure 11). The

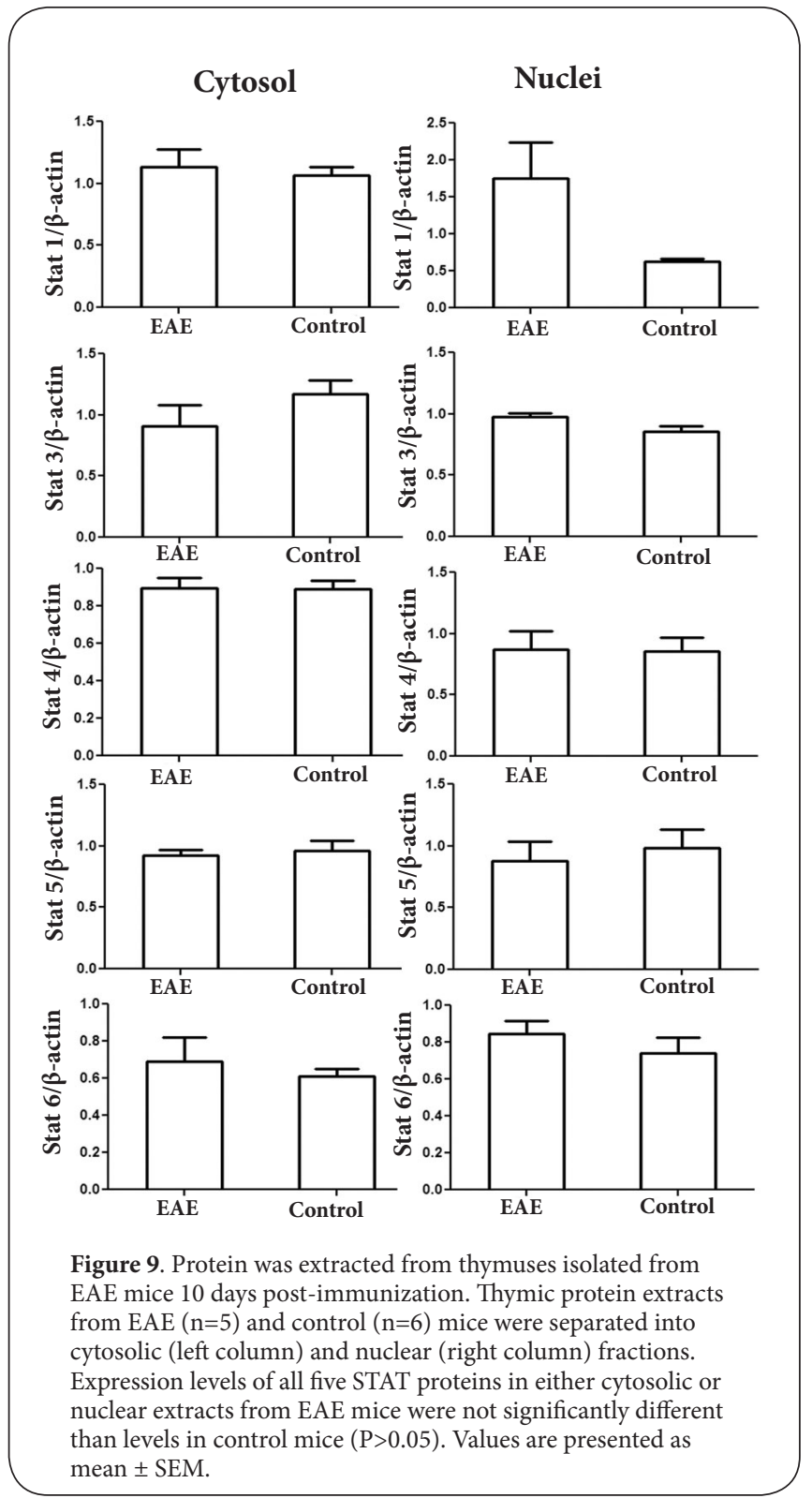

intensity of the immunostaining for all splenic STAT proteins was also stronger in spleen sections from control mice than in spleen sections from EAE mice (Figure 11).

\section{Discussion}

EAE is a T cell mediated CNS disease $[29,30]$. Although the relative roles of Th1 $[31,32]$ or Th17 [4] or both T cell lineages are still being examined, induction of EAE by adoptive transfer of either activated Th1 or Th17 cells [6,32] further reinforces the idea that $E A E$, and possibly human $M S$, are $T$ cell mediated autoimmune CNS diseases. Enlargement of the spleen and lymph nodes observed in EAE mice in the current study is consistent with proliferation of lymphatic cells. The detectable physical expansion was restricted to secondary 


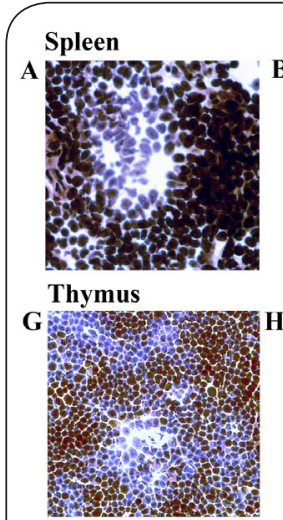

Stat1
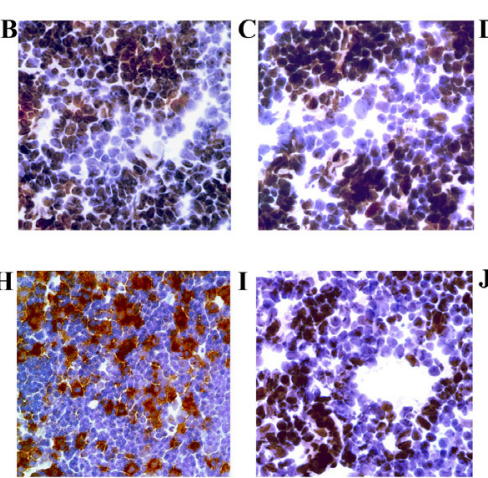

Stat2

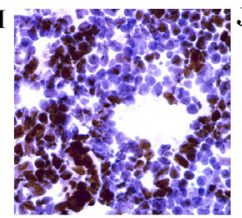

Stat3
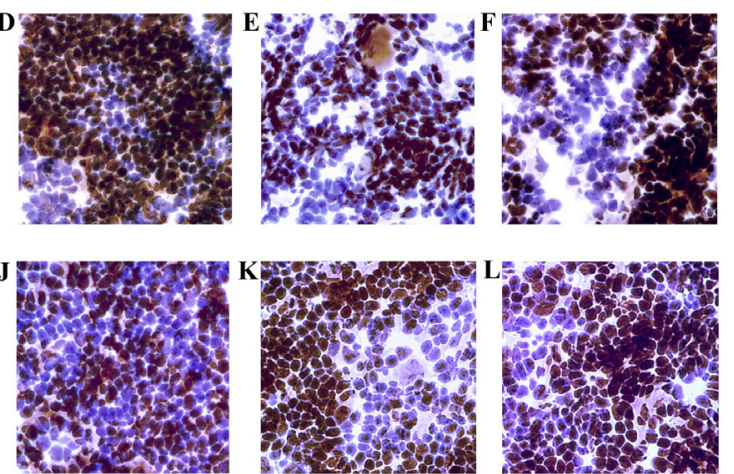

Stat4

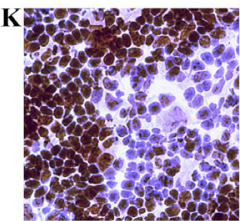

Stat5

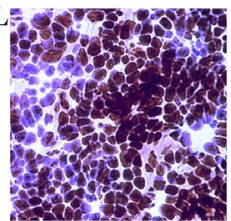

Stat6

Figure 10. Representative sections cut from spleen (A-F, top row) and thymus (G-L, bottom row) of control mice were labeled by immunohistochemistry with antibodies to STAT1 (A and G), STAT2 (B and H), STAT3 (C and I), STAT4 (D and J), STAT5 (E and K) and STAT6 (F and L). The dark brown nuclear stain represents STAT antibodies binding to each specific STAT protein. In spleen (A-F), all six STAT proteins were mainly localized in the T cell area of the white pulp. Immunostaining of all STAT proteins localized within cell nuclei in the spleen (A-F). In the thymus (G-L), immunostaining for all STAT proteins was also confined to the nuclei, except STAT2 $(\mathbf{H})$, which was localized in both cytoplasm and nuclei. Magnification $=400 \mathrm{X}$.

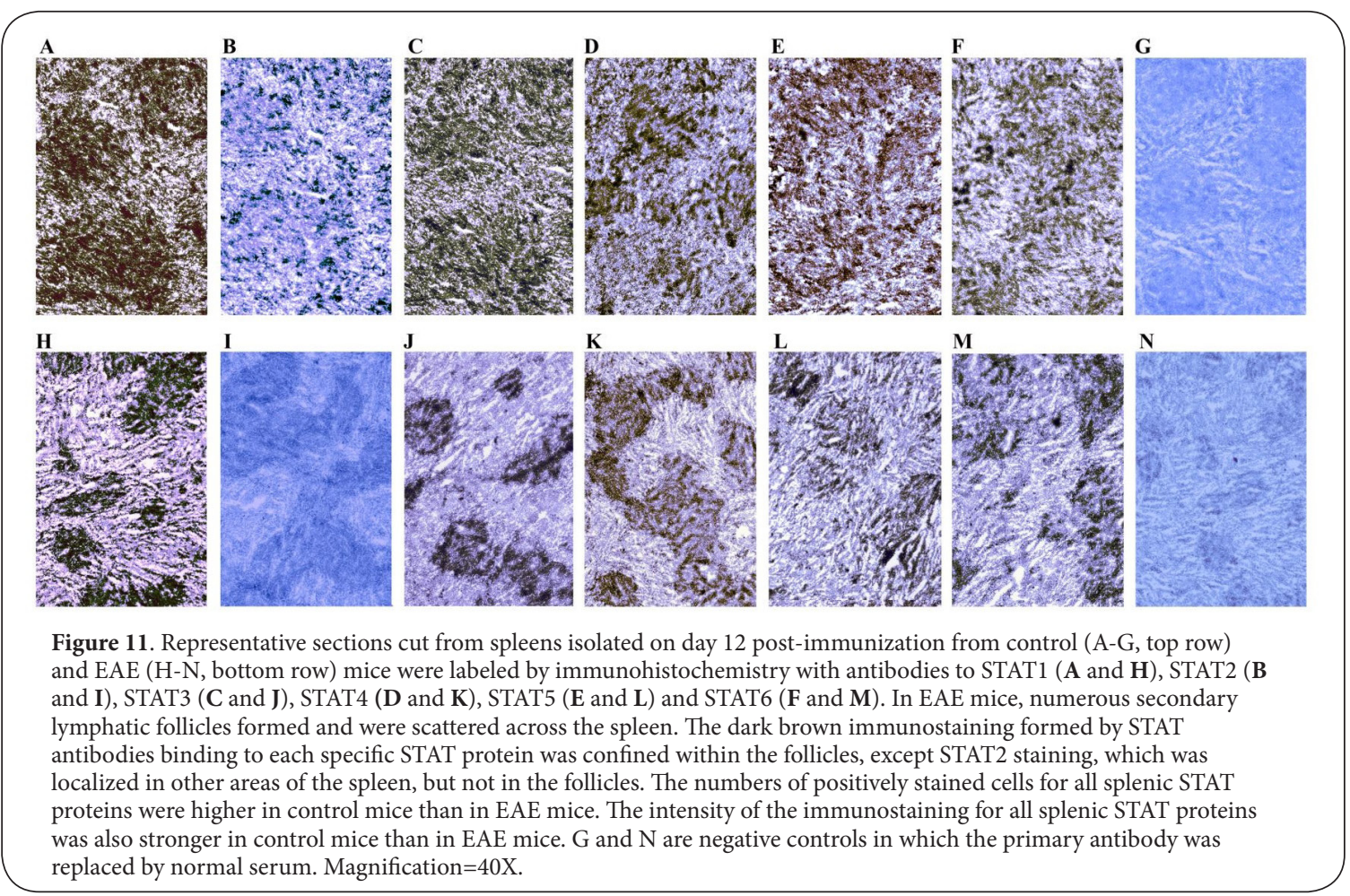

lymphatic organs, with no visible change in thymus after $E A E$ induction. While these findings may be expected due to the recognized role of T cells in EAE pathogenesis, interestingly a prior study reported a noted decrease in the overall weight of the spleen after EAE induction [33], in which homogenized brain tissue was used to induce EAE in Lewis rats and spleen weight was recorded at the time of death around 25 days post-immunization. In the current study, spleen weight was measured earlier, through the course of EAE development, on days 5, 10 and 12 post-immunization. Different experimental factors may account for the contrary observations, such as different species (mice vs rats), the antigens used to produce EAE (PLP vs whole brain homogenate), and the timing of recorded spleen weight (EAE development vs chronic phase of EAE).

To explore potential pathological mechanisms driving $T$ 
Xuan Wu et al. Immunology Innovation 2013,

cell expansion in spleen and lymph nodes of EAE mice, we examined expression of all members of the STAT family during the course of EAE development. The STAT protein family is involved in a major signaling pathway regulating Th1 and Th17 differentiation $[\mathbf{2 2}, \mathbf{2 8 , 3 4 , 3 5 ]}$. STAT proteins are mainly activated through phosphorylation by Janus kinase (Jak) family kinases $[36,37]$. Upon cytokine binding, activated Jaks phosphorylate tyrosine residues on the cytokine receptor that serve as docking sites for STAT proteins $[8,36,37]$. This promotes phosphorylation of STAT, leading to its release from the cytokine receptor, dimerization, and translocation into the nucleus. STAT dimers then bind promoter regions of cytokine-inducible genes and activate gene transcription $[36,37]$, facilitating T cell proliferation and differentiation.

Distinct functions of individual STAT family members have been suggested by analysis of individual gene knockout mice $[38,39]$. STAT4 is activated mainly by IL-12 and type I IFNs, and it functions predominantly in promotion of Th1 cell differentiation [40]. STAT6 is activated in response to IL-4 and functions as a molecular switch for initiation of the Th2 cell differentiation program $[\mathbf{4 0 , 4 1 ]}$. After activation by IL-6, STAT3 triggers Th17 commitment [22]. On the other hand, IL2-activated STAT5 facilitates Treg cell differentiation [10,28].

In EAE, studies using mice containing deletions of individual STAT family members suggest variable effects of this family on demyelinating disease. STAT6-deficient mice develop more severe EAE than wild-type mice [23]. Similarly, STAT1 knockout mice are highly susceptible to EAE and develop more severe and accelerated disease with atypical neuropathologic features [18]. However, mice deficient in STAT4 are resistant to EAE, with minimal inflammatory infiltrates observed in the CNS [23]. STAT3 is essential for early embryonic development [42], therefore isolated function of STAT3 in EAE can't be assessed by conventional gene knockout. Thus, important functions of specific STATs are recognized in EAE, but overall changes and interplay of members of this family are not well understood. In addition it is not known whether STAT proteins play a more critical role in development of myelin reactive $T$ cells in the peripheral immune system, or modulate entry of pathogenic T cells into the CNS and mediate localized tissue responses. It is for this reason that all six members of the STAT family were analyzed in the primary (thymus) and secondary (spleen and lymph nodes) lymphatic organs during EAE development.

Results show that on day 12 post-immunization, a time when clinical EAE nears its peak [27], protein levels of five of the six STAT family members (all except STAT2) were downregulated in spleen, whereas in thymus only STAT5 decreased significantly. Downregulation of STAT expression began even earlier, and progressed during EAE induction, as expression of most STAT family members in spleen began to decline by day 5 postimmunization, with further decreases found on day 10 . In lymph nodes, expression of STAT family members followed a similar pattern, but was more delayed in onset, with expression of all family members in lymph nodes of EAE mice equal to levels in control mice 5 days post-immunization, but expression of all STAT proteins, except STAT1, were decreased on day 10. This study provides the first comprehensive analysis of STAT protein expression during EAE development in critical primary and secondary lymphatic organs in vivo. A previous study [43] reported expression of STATs 1-6 was significantly enhanced in brain and spinal cord of EAE rats. Interestingly, the cells expressing STATs in the CNS [43] were astrocytes and microglia, not T cells, and STAT expression in spleen, lymph nodes and thymus were not reported. Another recent study [44] examined Jak-STAT expression in vitro, in splenocytes isolated from EAE animals. The authors demonstrate that amelioration of EAE by Plumbagin, a natural bicyclic naphthoquinone, is associated with downregulation of the JAK-STAT pathway, as opposed to our results suggesting downregulation is associated with induction of the EAE disease itself. Differences may be seen because our results represent effects on splenic and lymphatic STAT expression in vivo, while they measured expression in vitro after isolation of splenocytes from EAE animals.

While prior analysis of STAT knockout mice demonstrated distinct, sometimes opposite, functions of individual STAT family members in EAE, our results show almost all members decrease over a similar time course in spleen and lymph nodes of EAE mice. Germline knockout studies analyze a zero (knockout) vs all (wild type) effect of a given gene, while the downregulation of the STAT pathway in EAE spleen and lymph nodes is a gradual and progressive process, and most STATs were not turned off completely even by day 12 postimmunization. Also, the complex interplay between all STAT proteins together, along with other pathways functioning in primary and secondary lymphatic organs, may be orchestrated in an orderly fashion through the development of EAE. This may not be replaced by analysis of the absence of one individual gene. Therefore, it is also important to consider the overall pattern of changes in this family in conjunction with individual gene knockout data in order to extend and expand our understanding of the function of the STAT family in mediating EAE.

The significance and mechanism underlying the decrease of almost all STAT family members in spleen and lymph nodes of EAE mice is not yet understood, although prior studies and the current data suggest possible important mechanisms. Previous studies described a number of negative regulators of the JakSTAT signaling pathway, including tyrosine phosphatases [45], suppressors of cytokine signaling (SOCSs, 46), and protein inhibitors of activated STAT (PIASs, 45). STAT signaling is also regulated by STAT acetylation through Sirtuin 1 [47]. Future studies of these regulators should be considered to determine the cause of the massive downregulation of splenic and lymphatic STAT proteins associated with EAE development. Nonetheless, the suppression of STAT expression suggests the biological importance of this signaling pathway in EAE induced inflammatory $T$ cell proliferation and differentiation. Whether an alternative cellular signaling pathway replaces the 
Xuan Wu et al. Immunology Innovation 2013,

http://www.hoajonline.com/journals/pdf/2053-213X-1-3.pdf

STAT system in EAE T cells, or inhibition of the splenic STAT system is a prerequisite for normal T cells to be transformed into myelin reactive T cells merits further study.

Observed changes in expression of specific STAT family members in the current study may suggest potential mechanisms by which STAT signaling modulates EAE development. Interestingly, STAT5 was the only protein which decreased significantly in thymus upon EAE induction. A human STAT5 mutation results in severe immunodeficiency [48], and STAT5 facilitates regulatory T cells, not Th1, Th2 or Th17 differentiation [24], thus it is possible STAT5 downregulation reduces Treg populations that could inhibit EAE. Lack of thymic enlargement and absence of any change in expression of other STAT proteins in thymus suggests this pathway is more important for $\mathrm{T}$ cell proliferation in the secondary lymphatic organs.

Another distinct and isolated change occurred in lymph nodes, where expression of all STAT family members except STAT1 decreased on day 10 post-immunization. STAT1 knockout mice are more prone to EAE and develop more severe and accelerated disease [18]. Thus, sustained STAT1 expression in EAE lymph nodes may act as one mechanism to fight against the occurrence and progression of the disease after EAE induction.

In addition to enlargement in the size of the spleen, histological analysis revealed tissue reorganization and redistribution of the localization of STAT proteins. There are many newly formed secondary follicles, which explain the physical enlargement of EAE spleen. All STAT proteins except STAT2 were localized mainly in T cell areas of the white pulp of control mice and in T cell areas of spleen follicles of EAE mice, consistent with prior studies suggesting the STAT pathway may regulate $T$ cell proliferation and differentiation $[22,28,34,35]$. The distribution of STAT 2 differed from other STAT proteins. Notably, STAT2 was the only protein not restricted to nuclei, but found also in cytoplasm of the thymus. Moreover, in spleen STAT2 was localized to other cell types, but not the T cell area. The physiological implication of the difference in cellular distribution of STAT2 is not clear, although it suggests that this member of the STAT family, unlike other STATs, may not play a prominent role in EAE development.

\section{Conclusion}

We present here detailed expression analysis of all six members of the STAT family in thymus, lymph nodes and spleen through the development phase of EAE in mice. Downregulation of splenic and lymphatic STAT protein expression started on day 5 post-immunization, and progressed to nearly undetectable levels by day 12 , which was in contrast with almost steady expression of STAT proteins in thymus of EAE mice. Decreased STAT expression was accompanied by physical enlargement of the spleen, histological remodeling of the microstructure and proliferation of T cell areas in EAE spleen. All STATs except STAT2 were mainly confined to $T$ cell areas in spleen, whereas thymic STATs were distributed in a protein specific manner. Our data suggest that downregulation of almost all STAT signaling is important for pathologic transformation of inflammatory T cells during EAE development.

\section{Competing interests}

The authors declare that they have no competing interests.

Authors' contributions

\begin{tabular}{|l|c|c|c|c|}
\hline Authors' contributions & WXW & LZ & KED & KSS \\
\hline Research concept and design & $\checkmark$ & -- & -- & $\checkmark$ \\
\hline Collection and/or assembly of data & $\checkmark$ & $\checkmark$ & $\checkmark$ & -- \\
\hline Data analysis and interpretation & $\checkmark$ & -- & -- & $\checkmark$ \\
\hline Writing the article & $\checkmark$ & -- & -- & -- \\
\hline Critical revision of the article & $\checkmark$ & -- & -- & $\checkmark$ \\
\hline Final approval of article & $\checkmark$ & -- & -- & -- \\
\hline Statistical analysis & $\checkmark$ & -- & -- & $\checkmark$ \\
\hline
\end{tabular}

Acknowledgement

This work was supported by NIH EY019014, NMSS RG 4214-A-1, Research to Prevent Blindness, and the F. M. Kirby Foundation.

\section{Publication history}

Editor: Myron R Szewczuk Queen's University Canada.

EIC: Harry W. Schroeder, Jr University of Alabama at Birmingham USA.

Received: 19-Sep-2013 Revised: 18-Oct-2013

Accepted: 25-Oct-2013 Published: 02-Nov-2013

\section{References}

1. Furtado GC, Olivares-Villagomez D, Curotto de Lafaille MA, Wensky AK, Latkowski JA and Lafaille JJ. Regulatory T cells in spontaneous autoimmune encephalomyelitis. Immunol Rev. 2001; 182:122-34. | Article | PubMed

2. Mix E, Meyer-Rienecker H, Hartung HP and Zettl UK. Animal models of multiple sclerosis--potentials and limitations. Prog Neurobiol. 2010; 92:386-404. | Article | PubMed

3. Dal Canto MC, Melvold RW, Kim BS and Miller SD. Two models of multiple sclerosis: experimental allergic encephalomyelitis (EAE) and Theiler's murine encephalomyelitis virus (TMEV) infection. A pathological and immunological comparison. Microsc Res Tech. 1995; 32:215-29. | Article | PubMed

4. Kroenke MA, Carlson TJ, Andjelkovic AV and Segal BM. IL-12- and IL-23modulated T cells induce distinct types of EAE based on histology, CNS chemokine profile, and response to cytokine inhibition. J Exp Med. 2008; 205:1535-41. | Article | PubMed Abstract | PubMed Full Text

5. Fletcher JM, Lalor SJ, Sweeney CM, Tubridy $\mathrm{N}$ and Mills $\mathrm{KH}$. T cells in multiple sclerosis and experimental autoimmune encephalomyelitis. Clin Exp Immunol. 2010; 162:1-11. | Article | PubMed Abstract | PubMed Full Text

6. McRae BL, Kennedy MK, Tan LJ, Dal Canto MC, Picha KS and Miller SD. Induction of active and adoptive relapsing experimental autoimmune encephalomyelitis (EAE) using an encephalitogenic epitope of proteolipid protein. J Neuroimmunol. 1992; 38:229-40. | Article | PubMed

7. O'Shea JJ, Lahesmaa R, Vahedi G, Laurence A and Kanno Y. Genomic views of STAT function in CD4+ T helper cell differentiation. Nat Rev Immunol. 2011; 11:239-50. | Article | PubMed Abstract | PubMed Full Text

8. Ihle JN. STATs: signal transducers and activators of transcription. Cell. 1996; 84:331-4. | Article | PubMed 
Xuan Wu et al. Immunology Innovation 2013,

9. Natarajan $\mathrm{C}$ and Bright JJ. Curcumin inhibits experimental allergic encephalomyelitis by blocking IL-12 signaling through Janus kinaseSTAT pathway in T lymphocytes. J Immunol. 2002; 168:6506-13. | Article | PubMed

10. Jager A and Kuchroo VK. Effector and regulatory T-cell subsets in autoimmunity and tissue inflammation. Scand J Immunol. 2010; 72:17384. | Article | PubMed Abstract | PubMed Full Text

11. Jiang Z, Li H, Fitzgerald DC, Zhang GX and Rostami A. MOG(35-55) i.v suppresses experimental autoimmune encephalomyelitis partially through modulation of Th17 and JAK/STAT pathways. Eur J Immunol. 2009; 39:789-99. | Article | PubMed Abstract | PubMed Full Text

12. Muthian $G$ and Bright JJ. Quercetin, a flavonoid phytoestrogen, ameliorates experimental allergic encephalomyelitis by blocking IL-12 signaling through JAK-STAT pathway in T Iymphocyte. J Clin Immunol. 2004; 24:542-52. | Article | PubMed

13. Muthian G, Raikwar HP, Johnson C, Rajasingh J, Kalgutkar A, Marnett $\mathrm{LJ}$ and Bright JJ. COX-2 inhibitors modulate IL-12 signaling through JAK-STAT pathway leading to Th1 response in experimental allergic encephalomyelitis. J Clin Immunol. 2006; 26:73-85. | Article | PubMed

14. Muthian G, Raikwar HP, Rajasingh J and Bright JJ. 1,25 Dihydroxyvitamin-D3 modulates JAK-STAT pathway in IL-12/IFNgamma axis leading to Th1 response in experimental allergic encephalomyelitis. J Neurosci Res. 2006; 83:1299-309. | Article | PubMed

15. Qin X, Guo BT, Wan B, Fang L, Lu L, Wu L, Zang YQ and Zhang JZ. Regulation of Th1 and Th17 cell differentiation and amelioration of experimental autoimmune encephalomyelitis by natural product compound berberine. J Immunol. 2010; 185:1855-63. | Article | PubMed

16. Mitchell TJ and John S. Signal transducer and activator of transcription (STAT) signalling and T-cell lymphomas. Immunology. 2005; 114:301-12. | Article | PubMed Abstract | PubMed Full Text

17. Wang Y, Evans JT, Rodriguez F, Fields P, Mueller C, Chitnis T, Khoury SJ and Bynoe MS. A tale of two STAT6 knock out mice in the induction of experimental autoimmune encephalomyelitis. J Neuroimmunol. 2009; 206:76-85. | Article | PubMed Abstract | PubMed Full Text

18. Bettelli E, Sullivan B, Szabo SJ, Sobel RA, Glimcher LH and Kuchroo VK. Loss of T-bet, but not STAT1, prevents the development of experimental autoimmune encephalomyelitis. J Exp Med. 2004; 200:79-87. | Article | PubMed Abstract | PubMed Full Text

19. Kaplan MH, Sun YL, Hoey T and Grusby MJ. Impaired IL-12 responses and enhanced development of Th2 cells in Stat4-deficient mice. Nature. 1996; 382:174-7. I Article I PubMed

20. Thierfelder WE, van Deursen JM, Yamamoto K, Tripp RA, Sarawar SR, Carson RT, Sangster MY, Vignali DA, Doherty PC, Grosveld GC and Ihle JN. Requirement for Stat4 in interleukin-12-mediated responses of natural killer and T cells. Nature. 1996; 382:171-4. | Article | PubMed

21. Qu Z, Fu J, Ma H, Zhou J, Jin M, Mapara MY, Grusby MJ and Xiao G. PDLIM2 restricts Th1 and Th17 differentiation and prevents autoimmune disease. Cell Biosci. 2012; 2:23. | Article | PubMed Abstract | PubMed Full Text

22. Hirahara K, Ghoreschi K, Laurence A, Yang XP, Kanno Y and O'Shea JJ. Signal transduction pathways and transcriptional regulation in Th17 cell differentiation. Cytokine Growth Factor Rev. 2010; 21:425-34. | Article | PubMed Abstract | PubMed Full Text

23. Chitnis T, Najafian N, Benou C, Salama AD, Grusby MJ, Sayegh MH and Khoury SJ. Effect of targeted disruption of STAT4 and STAT6 on the induction of experimental autoimmune encephalomyelitis. J Clin Invest. 2001; 108:739-47. | Article | PubMed Abstract | PubMed Full Text

24. Cohen AC, Nadeau KC, Tu W, Hwa V, Dionis K, Bezrodnik L, Teper A, Gaillard M, Heinrich J, Krensky AM, Rosenfeld RG and Lewis DB. Cutting edge: Decreased accumulation and regulatory function of CD4+ CD25(high) T cells in human STAT5b deficiency. J Immunol. 2006; 177:2770-4. | Article | PubMed

25. Maier J, Kincaid C, Pagenstecher A and Campbell IL. Regulation of signal transducer and activator of transcription and suppressor of cytokine-signaling gene expression in the brain of mice with astrocytetargeted production of interleukin-12 or experimental autoimmune encephalomyelitis. Am J Pathol. 2002; 160:271-88. | Article | PubMed Abstract | PubMed Full Text

26. Zaheer S, Wu Y, Bassett J, Yang B and Zaheer A. Glia maturation factor regulation of STAT expression: a novel mechanism in experimental autoimmune encephalomyelitis. Neurochem Res. 2007; 32:2123-31. | Article | PubMed

27. Shindler KS, Guan Y, Ventura E, Bennett J and Rostami A. Retinal ganglion cell loss induced by acute optic neuritis in a relapsing model of multiple sclerosis. Mult Scler. 2006; 12:526-32. | Article | PubMed

28. Adamson AS, Collins K, Laurence A and O'Shea JJ. The Current STATus of lymphocyte signaling: new roles for old players. Curr Opin Immunol. 2009; 21:161-6. | Article | PubMed Abstract | PubMed Full Text

29. Ercolini AM and Miller SD. Mechanisms of immunopathology in murine models of central nervous system demyelinating disease. J Immunol. 2006; 176:3293-8. | Article | PubMed

30. Goverman J. Autoimmune T cell responses in the central nervous system. Nat Rev Immunol. 2009; 9:393-407. I Article I PubMed Abstract I PubMed Full Text

31. Nishikomori R, Usui T, Wu CY, Morinobu A, O'Shea JJ and Strober W. Activated STAT4 has an essential role in Th1 differentiation and proliferation that is independent of its role in the maintenance of IL12R beta 2 chain expression and signaling. J Immunol. 2002; 169:438898. | Article | PubMed

32. Stromnes IM, Cerretti LM, Liggitt D, Harris RA and Goverman JM. Differential regulation of central nervous system autoimmunity by T(H)1 and T(H)17 cells. Nat Med. 2008; 14:337-42. | Article I PubMed Abstract | PubMed Full Text

33. Hara N, Yoshida S, Takai N, Saito T and Tanaka R. [Morphological changes of the thymus and spleen with acute experimental allergic encephalomyelitis (EAE) in Lewis rats]. No To Shinkei. 1986; 38:81-5. | PubMed

34. Murphy KM and Reiner SL. The lineage decisions of helper T cells. Nat Rev Immunol. 2002; 2:933-44. | Article | PubMed

35. Chen Z, Laurence A and O'Shea JJ. Signal transduction pathways and transcriptional regulation in the control of Th17 differentiation. Semin Immunol. 2007; 19:400-8. | Article | PubMed Abstract | PubMed Full $\underline{\text { Text }}$

36. Heim MH. The Jak-STAT pathway: cytokine signalling from the receptor to the nucleus. J Recept Signal Transduct Res. 1999; 19:75-120. | Article I PubMed

37. Aaronson DS and Horvath CM. A road map for those who don't know JAK-STAT. Science. 2002; 296:1653-5. | Article | PubMed

38. Hoey T, Zhang S, Schmidt N, Yu Q, Ramchandani S, Xu X, Naeger LK, Sun $\mathrm{YL}$ and Kaplan $\mathrm{MH}$. Distinct requirements for the naturally occurring splice forms Stat4alpha and Stat4beta in IL-12 responses. EMBO J. 2003; 22:4237-48. | Article | PubMed Abstract | PubMed Full Text

39. Lund RJ, Chen Z, Scheinin J and Lahesmaa R. Early target genes of IL-12 and STAT4 signaling in th cells. J Immunol. 2004; 172:6775-82. | Article I PubMed

40. Kaplan MH and Grusby MJ. Regulation of T helper cell differentiation by STAT molecules. J Leukoc Biol. 1998; 64:2-5. | Article I PubMed

41. Takeda K, Tanaka T, Shi W, Matsumoto M, Minami M, Kashiwamura S, Nakanishi K, Yoshida N, Kishimoto T and Akira S. Essential role of Stat6 in IL-4 signalling. Nature. 1996; 380:627-30. | Article I PubMed

42. Takeda K, Noguchi K, Shi W, Tanaka T, Matsumoto M, Yoshida N, Kishimoto T and Akira S. Targeted disruption of the mouse Stat3 gene leads to early embryonic lethality. Proc Natl Acad Sci U S A. 1997; 94:3801-4. | Article | PubMed Abstract | PubMed Full Text

43. Jee $Y$, Kim G, Tanuma N and Matsumoto Y. STAT expression and localization in the central nervous system during autoimmune encephalomyelitis in Lewis rats. J Neuroimmunol. 2001; 114:40-7. | Article | PubMed

44. Jia Y, Jing J, Bai Y, Li Z, Liu L, Luo J, Liu M and Chen H. Amelioration of experimental autoimmune encephalomyelitis by plumbagin through down-regulation of JAK-STAT and NF-kappaB signaling pathways. PLOS One. 2011; 6:e27006. | Article | PubMed Abstract | PubMed Full Text 
Xuan Wu et al. Immunology Innovation 2013,

http://www.hoajonline.com/journals/pdf/2053-213X-1-3.pdf

45. Chen W, Daines MO and Khurana Hershey GK. Turning off signal transducer and activator of transcription (STAT): the negative regulation of STAT signaling. J Allergy Clin Immunol. 2004; 114:476-89. | Article | PubMed

46. Starr R, Willson TA, Viney EM, Murray LJ, Rayner JR, Jenkins BJ, Gonda TJ, Alexander WS, Metcalf D, Nicola NA and Hilton DJ. A family of cytokineinducible inhibitors of signalling. Nature. 1997; 387:917-21. | Article | PubMed

47. Wieczorek M, Ginter T, Brand P, Heinzel T and Kramer OH. Acetylation modulates the STAT signaling code. Cytokine Growth Factor Rev. 2012; 23:293-305. | Article | PubMed

48. Yao Z, Cui Y, Watford WT, Bream JH, Yamaoka K, Hissong BD, Li D, Durum SK, Jiang $Q$, Bhandoola A, Hennighausen $L$ and $O$ 'Shea JJ. Stat5a/b are essential for normal lymphoid development and differentiation. Proc Natl Acad Sci U S A. 2006; 103:1000-5. | Article | PubMed Abstract | PubMed Full Text

\section{Citation:}

Wu WX, Zuo L, Dine KE and Shindler KS. Decreased signal transducers and activators of transcription (STAT) protein expression in lymphatic organs during EAE development in mice. Immunol Innov. 2013; 1:3.

http://dx.doi.org/10.7243/2053-213X-1-3 